\title{
АСОРТИМЕНТНА ХАРАКТЕРИСТИКА ПРОСТАТОПРОТЕКТОРІВ, ЗАРЕЄСТРОВАНИХ В УКРАЇНІ, РЕСПУБЛІЦІ ПОЛЬЩА ТА РЕСПУБЛІЦІ БІЛОРУСЬ
}

\author{
(C) І. В. Гадяк' ${ }^{1}$ Б. П. Громовик ${ }^{2}$ \\ Івано-Франківський національний медичний університет ${ }^{1}$ \\ Львівський національний медичний університет імені Данила Галицького² \\ igadyak@ukr.net \\ hromovyk@gmail.com
}

\begin{abstract}
Мета роботи. Вивчення особливостей фрормування асортименту лікарських засобів (ЛЗ) для лікування простатиту в Україні, Республіці Польща (РП) та Республіці Білорусь (РБ).

Матеріали і методи. Матеріали дослідження - дані офріційних джерел щодо реєстрації лЗ в Україні, РП та РБ станом на 01.08.2017 р. Методи дослідження - системний, статистичний, аналізу порівняння, ранжування, узагальнення.

Результати і обговорення. Встановлено, що в Україні набагато більше (в 1,3 раза) торгових назв (ТН) простатопротекторів (ПП), ніж у РБ, проте удвічі менше, ніж уРП. Лідерами серед зарубіжних країн-виробників в Україні $€$ Німеччина, Індія, Італія, Нідерланди, в РП - Німеччина, Велика Британія, Нідерланди, Франція, в РБ - Україна і Росія. У кожній з досліджуваних країн зареєстровані ПП виробництва лише 9 із сукупності 30 держав, а саме Німеччини, Італії, Нідерландів, Угорщини, РП, Іспанії, Румунії, Словенії та Чехії. Найбільшу частку усього асортименту зареєстрованих ТН ПП в Україні та РП займають антагоністи альфа-адренорецепторів, в РБ - інші препарати, що застосовують при доброякісній гіпертрофії передміхурової залози. Показано, що має місце використання контрактних фрорм виходу на досліджувані ринки. Виявлено, що на цих ринках існує висока залежність ПП від імпорту. Встановлено, що дев'ять з десяти ТН ПП на українському ринку зареєстровано у вигляді лікарських фрорм (ЛФ) для перорального застосування, решта - супозиторії і парентеральні ЛФ. На ринку РП присутні тільки ЛФ для перорального застосування. На ринку РБ понад чотири п'ятих ТН ПП представлені пероральними ЛФ, десята частина - супозиторіями, решта - парентеральними ЛФ.

Висновки. На підставі аналізу даних офріційних реєстрів ЛЗ України, РП і РБ станом на 01.08.2017 р. визначено особливі та схожі характеристики ринків цих держав за асортиментом ПП, структурою їх виробників і заявників, форм виходу на ринки, асортиментною залежністю від імпорту та видом ЛФ. Отримані результати є важливими для подальшого фрормування асортиментної політики щодо ПП в Україні.
\end{abstract}

Ключові слова: простатопротектори; державна реєстрація (перереєстрація); асортимент; виробники, заявники; орорми виходу на ринок індекс асортиментної залежності від імпорту; лікарська фрорма.

Вступ. Комплексна терапія хвороби передміхурової залози у чоловіків вимагає використання безпечних лікарських засобів (ЛЗ) - простатопротекторів (ПП). Тому удосконалення організації та підвищення якості фрармацевтичного забезпечення хворих із простатитом $€$ актуальним завданням охорони здоров'я населення. Серед наукових праць, тісно пов'язаних 3 напрямом досліджень, є роботи Дмитрієвського Д. І. та ін. [5], Короткова В. А. [4], Зайченко В. С. та ін. [2], в яких вивчено український ринок ПП за період 2011 р. - І квартал 2012 р. для фрормування цільового сегмента ПП лікарям-урологам, ринок ПП Казахстану порівняно з ринками Російської Федерації (РФ) та України станом на 04.06.2013 р., асортиментні і вартісні показники та тенденції споживання ПП на українському ринку з вересня 2015 р. до вересня 2016 р. щодо визначення маркетингових можливостей для вітчизня- ної фрармації. Зважаючи на ретроспективний характер зазначених вище публікацій та промислову спрямованість їх результатів, зокрема на створення вітчизняних ПП рослинного походження, та не актуальність ринку РФ, зацікавленість викликає характеристика ПП, зареєстрованих в Україні, Республіці Польща (РП) та Республіці Білорусь (РБ), з погляду асортименту за міжнародною непатентованою (МHН) чи загальноприйнятою (ЗПН) та торговою назвою (ТН), структури виробників і заявників, фрорм виходу на ці ринки, асортиментної залежності від імпорту та виду лікарської фрорми (ЛФ). Тому метою дослідження було вивчення особливостей формування асортименту лз для лікування простатиту в Україні, РП та РБ.

Матеріали і методи. Матеріалами дослідження були дані щодо терапевтичної підгрупи G04C «Препарати для лікування доброякісної гіперплазії передміхурової

ISSN 2312-0967. Pharmaceutical review. 2017. № 3 
Фармацевтичний менеджмент, маркетинг та логістика Pharmaceutical management, marketing and logistics

залози» Державного реєстру ЛЗ України [3], а також офріційних джерел щодо реєстрації ЛЗ у РП та РБ [6; 7] станом на 01.082017 р. У роботі були використані методи дослідження: системний, статистичний, аналізу порівняння, ранжування, узагальнення, а також алгоритм асортиментної характеристики та моніторингу національного і регіональних фрармацевтичних ринків [1].

Результати й обговорення. За даними досліджуваних офріційних реєстрів ЛЗ було зареєстровано (перереєстровано) ПП з трьох груп п'ятого рівня анатомо-терапевтичної хімічної класифрікаційної системи (табл. 1):

- в Україні 11 ЛЗ за МНН чи ЗПН у вигляді 43 ТН 82 різних ЛФ з урахування різних дозувань і фрасувань, які випускають43 виробники з 21 країни і зареєстровані 33 заявниками з 19 держав;

- у РП теж 11 лз за МНН або ЗПН у вигляді $85 \mathrm{TH}$ 131 ЛФ з урахуванням різних дозувань і фрасувань, які випускають 56 виробників 318 країн і зареєстровані 40 заявниками 313 держав.

- у РБ лише 9 ЛЗ за МНН або ЗПН у вигляді 32 ТН 56 різних ЛФ з урахуванням різних дозувань і фрасувань, які випускають 24 виробники 314 країн і зареєстровані 23 заявниками з 13 держав.

За даними таблиці 1 видно, що в Україні більше (в 1,3 раза) ТН ПП, ніж у РБ, проте удвічі менше, ніж у РП.
Найбільшу частку усього асортименту зареєстрованих ТН ПП в Україні та РП займають антагоністи альфраадренорецепторів - відповідно майже половину і дві п'ятих усіх ТН ПП. В РБ ця група ЛЗ на другому місці за обсягом зареєстрованих ТН - майже дві п'ятих усього асортименту ПП. При цьому першість у РБ за іншими препаратами, що застосовуються при доброякісній гіпертросрії передміхурової залози (понад двох п'ятих), які в Україні та РП займають друге місце за кількістю (близько третини) ТН. Найменше у досліджуваних країнах зареєстровано ТН ПП з групи інгібіторів тестостерон5-альфа-редуктази, а саме 16,3, 25,5 і 21,9\% відповідно.

Група антагоністів альфа-адренорецепторів в Україні представлена 21 ТН Л3 на основі 4 активних фрармацевтичних інгредієнтів (АФІ) (альфузозин, тамсулозин, теразозин, силодозин) та двох їх поєднаннях (тамсулозин і дутастерид та тамсулозин і соліфенацин). У РП в цій групі 34 ТН ЛЗ на основі 4 АФІ та двох їх поєднаннях (тамсулозин і дутастерид та тамсулозин і соліфенацин). У РБ групу антагоністів альсра-адренорецепторів представляють 12 ТН ПП на основі 3 АФІ (відсутня група альсузозину) та двох їх поєднань (тамсулозин і дутастерид та тамсулозин і соліфенацин). У трьох країнах в асортименті антагоністів альфра-адренорецепторів переважають ТН тамсулозину (76,2, 61,8 і 66,6 \% відповідно).

Таблиця 1. Асортимент ТН ПП, дозволених до застосування в Україні, РП і РБ

\begin{tabular}{|c|c|c|c|c|}
\hline \multirow{2}{*}{$\begin{array}{c}\text { МНH або ЗПн } \\
\text { ПП }\end{array}$} & \multirow{2}{*}{ Код АТХ } & \multicolumn{3}{|c|}{ Кількість зареєстрованих ТН, од. } \\
\hline & & Україні & РП & РБ \\
\hline \multicolumn{5}{|c|}{ G04CA - Антагоністи альфра-адренорецепторів } \\
\hline Альфузозин & G04CA01 & 1 & 8 & - \\
\hline Тамсулозин & G04CA02 & 16 & 21 & 8 \\
\hline Теразозин & G04CA03 & 1 & 2 & 1 \\
\hline Силодозин & G04CA04 & 1 & 1 & 1 \\
\hline Тамсулозин і дутастерид & G04CA52 & 1 & 1 & 1 \\
\hline Тамсулозин і соліфенацин & G04CA53 & 1 & 1 & 1 \\
\hline \multicolumn{2}{|l|}{ Всього G04CA } & 21 & 34 & 12 \\
\hline \multicolumn{2}{|l|}{ Частка, \% } & 48,8 & 40,0 & 37,5 \\
\hline \multicolumn{5}{|c|}{ G04CB - Інгібітори тестостерон-5-альфа-редуктази } \\
\hline Фінастерид & G04CB01 & 6 & 24 & 6 \\
\hline Дутастерид & G04CB02 & 1 & 1 & 1 \\
\hline \multicolumn{2}{|l|}{ Всього G04CB } & 7 & 25 & 7 \\
\hline \multicolumn{2}{|l|}{ Частка, \% } & 16,3 & 29,4 & 21,9 \\
\hline \multicolumn{5}{|c|}{ G04CX - Інші препарати, що застосовуються при доброякісній гіпертрофії передміхурової залози } \\
\hline Препарати сливи афрриканської & G04CX01 & 1 & 2 & - \\
\hline Пальми повзучої препарат & G04CX02 & 4 & 3 & 1 \\
\hline $\begin{array}{l}\text { Інші препарати (фріто та тваринного } \\
\text { походження) }\end{array}$ & G04CX10 & 10 & 21 & 12 \\
\hline \multicolumn{2}{|l|}{ Всього G04CX } & 15 & 26 & 13 \\
\hline \multicolumn{2}{|l|}{ Частка, \% } & 34,9 & 30,6 & 40,6 \\
\hline & Разом & 43 & 85 & 32 \\
\hline
\end{tabular}

ISSN 2312-0967. Фармацевтичний часопис. 2017. № 3 
Фармацевтичний менеджмент, маркетинг та логістика Pharmaceutical management, marketing and logistics

Основним представником групи тестостерон-5альфа-редуктази є ЛЗ на основі АФІ - фрінастерид. В Україні і РБ зареєстровано 6 ТН фрінастериду, у РП - 24 TH, а також по одному ЛЗ дутастериду у кожній з країн.

Л3 групи G04CX представлені трьома підгрупами ЗПН. При цьому лз сливи африканської зареєстровані в Україні і РП (один і два таких ЛЗ відповідно). ЛЗ з пальми повзучої в Україні присутні у вигляді 4, РП
- 3, РБ - 1 ЗПН. Препарати фріто та тваринного походження займають найбільший обсяг серед ПП групи G04CX: в Україні таких 66,6\%, у РП - 80,8\% і в РП $-92,3 \%$ ЗПН.

Вивчення структури реєстрації (перереєстрації) ПП за країнами- виробниками показало, що першість у кожній державі за вітчизняними виробниками (табл. 2). Лідерами серед зарубіжних країн-виробни-

Таблиця 2. Структура реєстрації (перереєстрації) ПП за країнами-виробниками і країнами-заявниками

\begin{tabular}{|c|c|c|c|c|c|c|c|c|c|c|c|c|}
\hline \multirow{3}{*}{ Країна } & \multicolumn{6}{|c|}{ Реєстрація (перереєстрація) виробниками ПП } & \multicolumn{6}{|c|}{ Реєстрація (перереєстрація) заявниками ПП } \\
\hline & \multicolumn{2}{|c|}{ Україна } & \multicolumn{2}{|c|}{ РП } & \multicolumn{2}{|c|}{ РБ } & \multicolumn{2}{|c|}{ Україна } & \multicolumn{2}{|c|}{ РП } & \multicolumn{2}{|c|}{ РБ } \\
\hline & $\begin{array}{c}\text { частка, } \\
\%\end{array}$ & ранг & $\begin{array}{c}\text { частка, } \\
\%\end{array}$ & ранг & $\begin{array}{c}\text { частка, } \\
\%\end{array}$ & ранг & $\begin{array}{c}\text { частка, } \\
\%\end{array}$ & ранг & $\begin{array}{c}\text { частка, } \\
\%\end{array}$ & ранг & $\begin{array}{c}\text { частка, } \\
\%\end{array}$ & ранг \\
\hline Україна & 21,7 & 1 & & & 11,7 & 2,5 & 27,3 & 1 & & & 13,1 & 2,5 \\
\hline Німеччина & 17,3 & 2 & 13,8 & 2 & 7,7 & 5,5 & 15,3 & 2 & 9,5 & 3,5 & 8,8 & 4,5 \\
\hline Індія & 6,5 & 4 & & & 7,7 & 5,5 & 6,2 & 3,5 & & & 4,3 & 9 \\
\hline Італія & 6,5 & 4 & 1,5 & 15,5 & 3,8 & 12 & & & & & & \\
\hline Нідерланди & 6,5 & 4 & 7,7 & 4,5 & 3,8 & 12 & 3,0 & 12 & 2,4 & 10,5 & 4,3 & 9 \\
\hline РП & 4,3 & 7 & 20,0 & 1 & 3,8 & 12 & 3,0 & 12 & 42,8 & 1 & & \\
\hline Угорщина & 4,3 & 7 & 4,6 & 9 & 7,7 & 5,5 & 6,2 & 3,5 & 2,4 & 10,5 & 8,8 & 4,5 \\
\hline США & 4,3 & 7 & & & 3,8 & 12 & & & & & & \\
\hline Болгарія & 2,2 & 15 & & & & & & & & & & \\
\hline $\begin{array}{c}\text { Велика } \\
\text { Британія }\end{array}$ & 2,2 & 15 & 9,3 & 3 & & & 3,0 & 12 & 7,1 & 4,5 & 4,3 & 9 \\
\hline В'єтнам & 2,2 & 15 & & & & & 3,0 & & & & & \\
\hline Греція & 2,2 & 15 & & & & & & & & & & \\
\hline Грузія & 2,2 & 15 & & & & & 3,0 & 12 & & & & \\
\hline Ісландія & 2,2 & 15 & 1,5 & 15,5 & & & 3,0 & 12 & 2,4 & 10,5 & & \\
\hline Іспанія & 2,2 & 15 & 6,2 & 7 & 3,8 & 12 & & & & & & \\
\hline Канада & 2,2 & 15 & & & & & 3,0 & 12 & & & & \\
\hline Румунія & 2,2 & 15 & 1,5 & 15,5 & 7,7 & 5,5 & & & & & 4,3 & 9 \\
\hline Словаччина & 2,2 & 15 & & & & & & & & & & \\
\hline Словенія & 2,2 & 15 & 3,1 & 11 & 3,8 & 12 & 3,0 & 12 & 2,4 & 10,5 & 4,3 & 9 \\
\hline Тайланд & 2,2 & 15 & & & & & 3,0 & 12 & & & & \\
\hline Чехія & 2,2 & 15 & 6,2 & 7 & 3,8 & 12 & 3,0 & 12 & 4,8 & 7,5 & & \\
\hline Франція & & & 7,7 & 4,5 & & & & & 9,5 & 3,5 & & \\
\hline Австрія & & & 3,1 & 11 & & & & & 7,1 & 4,5 & & \\
\hline Ірландія & & & 6,2 & 7 & & & 3,0 & 12 & 4,8 & 7,5 & 4,3 & 9 \\
\hline Фінляндія & & & 3,1 & 11 & & & & & 2,4 & 10,5 & & \\
\hline Мальта & & & 1,5 & 15,5 & & & & & & & & \\
\hline Швеція & & & 1,5 & 15,5 & & & & & 2,4 & 10,5 & & \\
\hline Данія & & & 1,5 & 15,5 & & & & & & & & \\
\hline РБ & & & & & 19,2 & 1 & & & & & 21,8 & 1 \\
\hline$P \Phi$ & & & & & 11,7 & 2,5 & & & & & 13,1 & 2,5 \\
\hline Австралія & & & & & & & 3,0 & 12 & & & & \\
\hline Литва & & & & & & & 3,0 & 12 & & & 4,3 & 9 \\
\hline Люксембург & & & & & & & 3,0 & 12 & & & & \\
\hline Швейцарія & & & & & & & 3,0 & 12 & & & & \\
\hline
\end{tabular}

ISSN 2312-0967. Pharmaceutical review. 2017. № 3 
Фармацевтичний менеджмент, маркетинг та логістика Pharmaceutical management, marketing and logistics

ків в Україні $є$ Німеччина, Індія, Італія, Нідерланди, в РП - Німеччина, Велика Британія, Нідерланди, Франція, в РБ - Україна і РФ. У кожній $з$ досліджуваних країн зареєстровані ПП виробництва лише 9 із сукупності 30 держав, а саме Німеччини, Італії, Нідерландів, Угорщини, РП, Іспанії, Румунії, Словенії та Чехії.

Досліджування структури реєстрації (перереєстрації) ПП за країнами-заявниками показало, що першість в кожній державі теж за вітчизняними заявниками. Лідерами серед зарубіжних заявників ПП в Україні насамперед $є$ Німеччина, Індія, Угорщина, в РП - Німеччина, Франція, в РБ - Україна, РФ. У кожній $з$ досліджуваних країн ПП заявлені лише 6 із сукупності 26 держав, а саме: Німеччини, Нідерландів, Угорщини, Великої Британії, Словенії та Ірландії.

При цьому в Україні і РБ зареєстровані ПП виробників і заявників з Індії, а в РП - вони відсутні. У свою чергу, в Україні і РП суттєву частку займають німецькі виробники і заявники ПП за відсутності таких із РФ, а в Білорусії - РФ та Україна.

На досліджуваних ринках одночасно присутні ПП 7 виробників: Астелас Фарма Юроп (Нідерланди), Каталент Німеччина Ебербах ГмбХ (Німеччина), Гедеон Ріхтер (Угорщина), Сінтон Хіспанія СЛ (Іспанія), KRKA (Словенія), ГлаксоСмітКляйн Фармасьютикалз С.А. (РП) та Рекордаті Індастріа Хіміка е Фармасевтіка (Італія). Розходження між числом країн-виробників та підприємств-виробників пояснюється тим, що на досліджуваних ринках присутні різні румунські та чеські виробники.

На українському ринку по 2 ТН ПП зареєстрували вітчизняні виробники: Лекхім-Харків та Технолог (м. Умань), а також іноземні виробники: Астелас Фарма Юроп Б.В. (Нідерланди), Др. Вільмар Швабе Гмбх і Ко.КГ (Німеччина), Сан Фармасьютикал Індастріз Лімітед (Індія). Решта підприємств запропонувала по одній ТН ПП.

Серед виробників на ринку РП лідируючі позиції займають іноземні виробники - Сінтон Хіспанія СЛ
(Іспанія) - 9 ТН, Сінтон БВ (Нідерланди) - 8 ТН, Оріон (Фінляндія) - 6 ТН, Стада (Німеччина) - 3 TH, Астелас Фарма Юроп (Нідерланди), Лек (Словенія) - по 2 ТН. Поміж польських виробників лідируючі позиції у Гал, Гербапол, Лек фрармасьютикалс, Пліва - по 4 ТН ПП, Адамед, Синоптіс Фарма - по 2 ТН ПП.

На ринку РБ по 2 ТН ПП зареєстрували Астелас Фарма Юроп (Нідерланди), Егіс (Угорщина), KRKA (Словенія), Лекхім-Харків (Україна), Нижфрарм (Росія). Всі інші виробники, у т. ч. 4 білоруські - Белмедпрепарати, Калина, Лекфарм, Мінськінтеркапс УП, зареєстрували по одній ТН ПП.

При вивченні асортименту встановлено, що в досліджуваних країнах одночасно зареєстровано 8 ПП, а саме: Омнік капс. та Омнік Окас таб. (Астелас Фарма Юроп, Нідерланди), Таніз капс. і Фінпрос таб. (KRKA, Словенія), Урорек капс. (Рекордаті, Італія), Дуодарт капс. (Каталент, Німеччина), Аводарт капс. (ГлаксоСмітКляйн, РП), Простамол Уно капс. (Берлін Хемі, Німеччина).

На ринках України та РП присутні такі ПП, як Фокусин капс. (АТ Санека Фармасьютикалз, Словакія), Проскар таб. (Мерк Шарп, Швейцарія), Пенестер таб. (Зентіва, Чехія), Польданен таб. (Гербаполь, Польща), а на ринках України та РБ - Тамсол капс. (Гедеон Ріхтер, Угорщина), Сетегис таб. (Егіс, Угорщина), Везомні таб. (Астелас, Нідерланди), Простан таб. (Технолог, Україна), супозиторії з олією насіння гарбуза (Монфарм, Україна), Простамед таб. (Др. Густав Кляйн ГмбХ, Німеччина).

Детальний аналіз виробників і заявників ПП показав, що має місце використання контрактних фрорм виходу на ринок досліджуваних країн, а саме: спільне виробництво і делегування реєстрації (перереєстрації) одному з виробників або дочірній організації одного з виробників чи іншій організації, а також делегування реєстрації (перереєстрації) дочірній або іншій організації (табл. 3-5).

Таблиця 3. Контрактні форми виходу з ПП на український ринок

\begin{tabular}{|c|c|c|}
\hline ТН ЛЗ & Організації-виробники & Організації-заявники \\
\hline 1 & 2 & 3 \\
\hline \multicolumn{3}{|c|}{ Спільне виробництво і делегування реєстрації (перереєстрації) одному з виробників } \\
\hline $\begin{array}{l}\text { Аденостерид } \\
\text {-Здоров'я }\end{array}$ & ТОВ "ФК "Здоров'я", Україна + ТОВ «Фармекс груп», Україна & ТОВ "ФК "Здоров'я", Україна \\
\hline Везомні & $\begin{array}{l}\text { Авара Фармасьютікал Текнолоджис Інк., США + Астеллас } \\
\text { Фарма Юроп Б.В., Нідерланди }\end{array}$ & $\begin{array}{l}\text { Астеллас Фарма Юроп Б.В., } \\
\text { Нідерланди }\end{array}$ \\
\hline $\begin{array}{c}\text { Простамол } \\
\text { Уно }\end{array}$ & $\begin{array}{l}\text { Берлін-Хемі АГ, Німеччина + Каталент Німеччина + Ебербах } \\
\text { ГмбХ, Німеччина + Менаріні-Фон Хейден ГмбХ, Німеччина + } \\
\text { Санофрі С.П.А, Італія }\end{array}$ & Берлін-Хемі АГ, Німеччина \\
\hline Тамсол & $\begin{array}{l}\text { "Гедеон Ріхтер Румунія" А.Т., Румунія + } \\
\text { ВАТ "Гедеон Ріхтер" , Угорщина }\end{array}$ & ВАТ "Гедеон Ріхтер", Угорщина \\
\hline Тамсулостад & $\begin{array}{l}\text { Ламп Сан Просперо Спа, Італія + Фамар А.В.Е. Антоусса, } \\
\text { Греція + Роттендорфр Фарма ГмбХ, Німеччина + Сінтон } \\
\text { Хіспанія С.Л., Іспанія + Стада Арцнайміттель /Сінтон БВ, } \\
\text { Німеччина/Нідерланди }\end{array}$ & $\begin{array}{l}\text { Стада Арцнайміттель АГ, } \\
\text { Німеччина }\end{array}$ \\
\hline
\end{tabular}

ISSN 2312-0967. Фармацевтичний часопис. 2017. № 3 
Фармацевтичний менеджмент, маркетинг та логістика Pharmaceutical management, marketing and logistics

Продовження табл. 3

\begin{tabular}{|c|c|c|}
\hline 1 & 2 & 3 \\
\hline Таніз & $\begin{array}{l}\text { КРКА, Словенія + Роттендорф Фарма ГмбХ, Німеччина + } \\
\text { Фамар А.В.Е., Греція + Сінтон Хіспанія С.Л., Іспанія }\end{array}$ & КРКА, Словенія \\
\hline Урофрін & Інтас Фармасьютикалз Лімітед, Індія + Актавіс АТ, Ісландія & Актавіс груп АТ, Ісландія \\
\hline \multicolumn{3}{|c|}{$\begin{array}{c}\text { Спільне виробництво і делегування реєстрації (перереєстрації) } \\
\text { дочірній організації одного з виробників }\end{array}$} \\
\hline Проскар & $\begin{array}{l}\text { AIAC Інтернешнл Фарма, ТОВ, США + Мерк Шарп і Доум } \\
\text { Лімітед, Велика Британія + Мерк Шарп і Доум Б.В, Нідерланди }\end{array}$ & $\begin{array}{l}\text { Мерк Шарп і Доум Ідеа Інк., } \\
\text { Швейцарія }\end{array}$ \\
\hline Флосін & $\begin{array}{l}\text { Фамар А.В.Е. Антоусса Плант, Греція + Роттендорф Фарма } \\
\text { ГмбХ, Німеччина + Менаріні-Фон Хейден ГмбХ, Німеччина + } \\
\text { Сінтон Хіспанія С.Л., Іспанія }\end{array}$ & $\begin{array}{l}\text { Менаріні Інтернешонал } \\
\text { Оперейшонс Люксембург С.А., } \\
\text { Люксембург }\end{array}$ \\
\hline \multicolumn{3}{|c|}{ Спільне виробництво і делегування реєстрації (перереєстрації) іншій організації } \\
\hline Тамсін Форте & $\begin{array}{l}\text { Сінтон Хіспанія, С.Л., Іспанія + Джі I Фармасьютікалс, } \\
\text { Болгарія }\end{array}$ & $\begin{array}{l}\text { Мега Лайфссайенсіз Пті Лтд., } \\
\text { Австралія }\end{array}$ \\
\hline Теніза & $\begin{array}{l}\text { Фамар А.В.Е. Антоусса Плант, Греція + Роттендорф Фарма } \\
\text { ГмбХ, Німеччина + Сінтон Хіспанія С.Л., Іспанія + Сінтон БВ, } \\
\text { Нідерланди }\end{array}$ & Актавіс груп АТ, Ісландія \\
\hline \multicolumn{3}{|c|}{ Делегування реєстрації (перереєстрації) дочірній організації } \\
\hline Аводарт & Глаксо СмітКляйн Фармасьютикалз С.А., Польща & $\begin{array}{l}\text { ГлаксоСмітКляйн Експорт } \\
\text { Лімітед, Велика Британія }\end{array}$ \\
\hline Урорек & Рекордаті Індастріа Хіміка е Фармасевтіка С.п.А., Італія & Рекордаті Аіленд Лтд, Ірландія \\
\hline \multicolumn{3}{|c|}{ Делегування реєстрації (перереєстрації) іншій організації } \\
\hline Дуодарт & Каталент Джермані Шорндорфр ГмбХ, Німеччина & $\begin{array}{l}\text { ГлаксоСмітКляйн Експорт } \\
\text { Лімітед, Велика Британія }\end{array}$ \\
\hline Омнімакс & Інтас Фармасьютикалс Лтд, Індія & ЗАТ "Максфарма Балтія", Литва \\
\hline Просталад & ПАТ "Біолік", Україна & $\begin{array}{l}\text { ТОВ "Українська фрармацев- } \\
\text { тична компанія", Україна }\end{array}$ \\
\hline Фокусин & АТ "Санека Фармасьютікалз", Словаччина & $\begin{array}{l}\text { ТОВ "Зентіва", Чеська } \\
\text { Республіка }\end{array}$ \\
\hline
\end{tabular}

Таблиця 4. Контрактні форми виходу з ПП на польський ринок

\begin{tabular}{|c|c|c|}
\hline ТН лЗ & Організації-виробники & Організації-заявники \\
\hline 1 & 2 & 3 \\
\hline \multicolumn{3}{|c|}{ Спільне виробництво і делегування реєстрації (перереєстрації) одному з виробників } \\
\hline Таніз & $\begin{array}{l}\text { КРКА, Словенія + Квінта аналітика СРО, Нідерланди + Сінтон } \\
\text { БВ, Нідерланди + Сінтон Хіспанія С.Л., Іспанія }\end{array}$ & \multirow[t]{3}{*}{ КРКА, Словенія } \\
\hline Таніз Ерас & $\begin{array}{l}\text { КРКА, Словенія + ТАД фрарма, Німеччина + Сінтон БВ, } \\
\text { Нідерланди + Сінтон Хіспанія С.Л., Іспанія }\end{array}$ & \\
\hline Фінпрос & Актавіс груп ГФ, Ісландія + КРКА, Словенія & \\
\hline $\begin{array}{l}\text { Фінастерид } \\
\text { Стада }\end{array}$ & $\begin{array}{l}\text { Керн фрарма Сл, Іспанія + Оріон, Фінляндія + Стада АГ, } \\
\text { Німеччина }\end{array}$ & Стада АГ, Німеччина \\
\hline Хитрін & $\begin{array}{l}\text { Аесіка квінбуругел лімітед, Велика Британія + Амдіфрарм } \\
\text { лімітед, Ірландія }\end{array}$ & Амдіфрарм лімітед, Ірландія \\
\hline \multicolumn{3}{|c|}{$\begin{array}{c}\text { Спільне виробництво і делегування реєстрації (перереєстрації) } \\
\text { дочірній організації одного з виробників }\end{array}$} \\
\hline Базетам & $\begin{array}{l}\text { АВД фрарма ГмБХ\&КО КГ, Німеччина + Пліва ЗФ СА, Польща + } \\
\text { Квінта-аналітика СРО, Чехія + Сінтон БВ, Нідерланди + Сінтон } \\
\text { Хіспанія СЛ, Іспанія }\end{array}$ & \multirow[t]{4}{*}{ Тева фрармасевтікалс СП, РП } \\
\hline $\begin{array}{c}\text { Базетам } \\
\text { ретард }\end{array}$ & $\begin{array}{l}\text { Фармахемі БВ, Нідерланди + Тева індастрія СРО, Чехія + Тева } \\
\text { фрарма СЛЮ, Іспанія + Тева Фармасевтікал ЛТД, Угорщина + } \\
\text { Тева санте СА, Франція + Тева ЮК ЛТД, Велика Британія }\end{array}$ & \\
\hline Лісрін & Пліва СА, Польща + Тева фрармасьютикалс, Угорщина & \\
\hline Фінамефр & $\begin{array}{l}\text { Фармахемі БВ, Нідерланди + Тева Фармасевтікал, Нідерланди } \\
\text { + Тева санте СА, Франція + Тева лТД, Велика Британія }\end{array}$ & \\
\hline
\end{tabular}

ISSN 2312-0967. Pharmaceutical review. 2017. № 3 
Фармацевтичний менеджмент, маркетинг та логістика Pharmaceutical management, marketing and logistics

Продовження табл. 4

\begin{tabular}{|c|c|c|}
\hline 1 & 2 & 3 \\
\hline Тамсуген & $\begin{array}{l}\text { Дженерікс лТД, Велика Британія + Макдермот лабораторіс, } \\
\text { Ірландія + Мілан Венгрія КФТ, Угорщина + Сінтон БВ, } \\
\text { Нідерланди + Сінтон Хіспанія Сл, Іспанія }\end{array}$ & $\begin{array}{l}\text { Дженерікс лТД, Велика } \\
\text { Британія }\end{array}$ \\
\hline Фінарід & Лек- АМ СП, РП + Салютас фрарма ГмБХ, Німеччина & \multirow[t]{2}{*}{ Сандоз ГмБХ, Австрія } \\
\hline Алфулек & $\begin{array}{l}\text { Лек фрармасьютикалс, Словенія + Лек СА, РП + Салютас } \\
\text { фарма, Німеччина }\end{array}$ & \\
\hline \multicolumn{3}{|c|}{ Спільне виробництво і делегування реєстрації (перереєстрації) іншій організації } \\
\hline Андростер & Керн фрарма, Іспанія + Оріон, Фінляндія + Польфрарма СА., РП & \multirow[t]{2}{*}{ Актавіс груп ГФ, Ісландія } \\
\hline Тамсуділ & Сінтон БВ, Нідерланди + Сінтон Хіспанія СЛ, Іспанія & \\
\hline Простамнік & $\begin{array}{l}\text { Квінта-аналітика СРО, Чехія + Сінтон БВ, Нідерланди + } \\
\text { Сінтон Хіспанія СЛ, Іспанія }\end{array}$ & $\begin{array}{l}\text { + Фарма Арцнайміттель ГмбХ, } \\
\text { Австрія }\end{array}$ \\
\hline Ранлосін & Ранбаксі ЛТД, Ірландія + Терапія СА, Румунія & Лек - АМ СП, РП \\
\hline Симастерид & Актавіс груп ГФ, Ісландія + Фармалі БВ, Нідерланди & Сімфрар СП, РП \\
\hline Таміс Прас & $\begin{array}{l}\text { Нормон СА, Іспанія + Сінтон БВ, Нідерланди + Сінтон } \\
\text { Хіспанія СЛ, Іспанія }\end{array}$ & Апотекс Юроп БВ, Нідерланди \\
\hline Фінаран & $\begin{array}{l}\text { Базікс ГмБХ, Німеччина + Керн фрарма Сл, Іспанія + Оріон, } \\
\text { Фінляндія }\end{array}$ & Ранбаксі СП, РП \\
\hline Упрокс & $\begin{array}{l}\text { Квінта-аналітика СРО, Чехія + Сінтон БВ, Нідерланди + } \\
\text { Сінтон Хіспанія СЛ, Іспанія }\end{array}$ & \multirow[t]{2}{*}{ Фарма проект СП, РП } \\
\hline Фінкста & Керн фрарма Сл, Іспанія + Оріон, Фінляндія & \\
\hline \multicolumn{3}{|c|}{ Делегування реєстрації (перереєстрації) дочірній організації } \\
\hline Аводарт & Глаксо СмітКляйн Фармасьютикалз С.А., РП & $\begin{array}{l}\text { ГлаксоСмітКляйн Експорт } \\
\text { Лімітед, Велика Британія }\end{array}$ \\
\hline Урорек & \multirow[t]{2}{*}{ Рекордаті Індастріа Хіміка е Фармасевтіка С.п.А., Італія } & Рекордаті Аіленд Лтд, Ірландія \\
\hline Упрокс XР & & Рекордаті, РП \\
\hline Корнам & Лек фрармасьютикалс, Словенія & Сандоз, Австрія \\
\hline Весікаре & Астелас фрарма Юроп БВ, Нідерланди & Астелас фрарма СП, РП \\
\hline Алфрабакс & Ранбаксі ЛТД, Ірландія & Ранбаксі СП, РП \\
\hline Пропеція & \multirow[t]{2}{*}{ Мерк Шарп ЛтД, Велика Британія } & \multirow[t]{2}{*}{ МШД, РП } \\
\hline Проскар & & \\
\hline \multicolumn{3}{|c|}{ Делегування реєстрації (перереєстрації) іншій організації } \\
\hline Дуодарт & Каталент Джермані Шорндорф ГмбХ, Німеччина & $\begin{array}{l}\text { ГлаксоСмітКляйн Експорт } \\
\text { Лімітед, Велика Британія }\end{array}$ \\
\hline Симлосін СР & Біоканол фрарма, Німеччина & Сімфрар СП, РП \\
\hline Апо-сріна & Апотекс Юроп БВ, Нідерланди & Актавіс груп ГФ, Ісландія \\
\hline Фінаген & Макдермот лабораторіс, Ірландія & $\begin{array}{l}\text { Дженерікс } \\
\text { Британія }\end{array}$ \\
\hline Незир & \multirow[t]{2}{*}{ Фармадокс хелскаре лтД, Мальта } & \multirow[t]{2}{*}{ Аксон, РП } \\
\hline Уронезир & & \\
\hline
\end{tabular}

Таблиця 5. Контрактні фрорми виходу з ПП на білоруський ринок

\begin{tabular}{|c|l|c|}
\hline ТН ЛЗ & \multicolumn{1}{|c|}{ Організації-виробники } & \multicolumn{1}{|c|}{ Організації-заявники } \\
\hline 1 & \multicolumn{1}{|c|}{2} & \multicolumn{1}{|c|}{3} \\
\hline \multicolumn{2}{|c|}{ Спільне виробництво і делегування реєстрації (перереєстрації) одному з виробників } \\
\hline Везомні & $\begin{array}{l}\text { Авара Фармасьютікал Текнолоджис Інк., США + Астеллас } \\
\text { Фарма Юроп Б.В., Нідерланди }\end{array}$ & $\begin{array}{l}\text { Астеллас Фарма Юроп Б.В., } \\
\text { Нідерланди }\end{array}$ \\
\hline Тамсулозин & $\begin{array}{l}\text { Сінтон Хіспанія, С.Л., Іспанія + ВАТ Борисовський завод } \\
\text { медицичних препаратів, РБ }\end{array}$ & $\begin{array}{l}\text { ВАТ Борисовський завод } \\
\text { медицичних препаратів, РБ }\end{array}$ \\
\hline $\begin{array}{c}\text { Фінастерид } \\
\text {-МІК }\end{array}$ & ПрАТ «Технолог», Україна + Мінськінтеркапс УП, РБ & Мінськінтеркапс УП, РБ \\
\hline
\end{tabular}

ISSN 2312-0967. Фармацевтичний часопис. 2017. № 3 
Фармацевтичний менеджмент, маркетинг та логістика Pharmaceutical management, marketing and logistics

Продовження табл. 5

\begin{tabular}{|c|c|c|}
\hline 1 & 2 & 3 \\
\hline Тамсол & Гедеон Ріхтер Румунія S.А./ Гедеон Ріхтер Ріс.Угорщина & Гедеон Ріхтер Ріс.,Угорщина \\
\hline \multicolumn{3}{|c|}{ Делегування реєстрації (перереєстрації) дочірній організації } \\
\hline Аводарт & ГлаксоСмітКляйн Фармасьютикалз С.А., РП & $\begin{array}{l}\text { ГлаксоСмітКляйн Експорт } \\
\text { Лімітед, Велика Британія }\end{array}$ \\
\hline Урорек & Рекордаті Індастріа Хіміка е Фармасевтіка С.п.А., Італія & Рекордаті Аіленд Лтд, Ірландія \\
\hline \multicolumn{3}{|c|}{ Делегування реєстрації (перереєстрації) іншій організації } \\
\hline Дуодарт & Каталент Джермані Шорндорф ГмбХ, Німеччина & $\begin{array}{l}\text { ГлаксоСмітКляйн Експорт } \\
\text { Лімітед, Велика Британія }\end{array}$ \\
\hline Фінація & Інтас Фамацевтікалс Лтд, Індія & Максфрарма Балтія UAB, Литва \\
\hline Простамол Уно & Каталент Джермані Евербах ГмбХ, Німеччина & Берлін-Хемі АГ, Німеччина \\
\hline
\end{tabular}

При цьому контрактні форми виходу на ринки України та РП використано для близько двох п'ятих ТН ПП (39,5 і 41,2 \% відповідно), а РБ - для понад однієї четвертої (28,1\%). Для двох ТН (Аводарт та Урорек) використано делегування реєстрації (перереєстрації) дочірній організації на всіх досліджуваних ринках. Чотири ТН ПП (Везомні, Простамол Уно, Тамсол і Таніз) на ринки України та РБ вийшли шляхом спільного виробництва і делегування реєстрації (перереєстрації) одному з виробників, одна ТН (Проскар) - спільного виробництва і делегування реєстрації (перереєстрації) дочірній організації одного з виробників. Делегування реєстрації (перереєстрації) іншій організації використана для виходу Дуодарту на ринки РП і РБ.

Вивченням асортиментної залежності від імпорту встановлено, що:

- в Україні індекс асортиментної залежності від імпорту ПП становив 0,78 (висока залежність), а усіх
Л3 - 0,7 (помітна залежність) (станом на 01.08.2017 р. у реєстрі було 12999 ЛЗ, з них іноземного виробництва - 9 041);

- у РП індекс асортиментної залежності від імпорту ПП становив 0,8 (висока залежність), а усіх Л3 - 0,66 (помітна залежність) (станом на 01.08.2017 р. у реєстрі було 17853 Л3, з них іноземного виробництва - 11 861);

- у РБ індекс асортиментної залежності від імпорту ПП становив 0,81 (висока залежність), а усіх Л3 - 0,72 (теж висока залежність) (станом на 01.08.2017 р. у реєстрі було 5784 Л3, з них іноземного виробництва - 4 145).

Таким чином, на досліджуваних ринках існує висока залежність ПП від імпорту, що на фоні помітної залежності за даними усіх заявлених Лз в Україні і РП та високої у РБ вказує на необхідність здійснювати розробку і виробництво власних ПП.

Результати аналізу асортименту ПП за ЛФ показали (табл. 6), що абсолютна більшість ТН ПП на укра-

Таблиця 6. Структура заявлених ПП за ЛФ

\begin{tabular}{|c|c|c|c|c|c|c|}
\hline \multirow{2}{*}{ Назва ЛФ } & \multicolumn{2}{|c|}{ Україна } & \multicolumn{2}{|c|}{ РП } & \multicolumn{2}{|c|}{ РБ } \\
\hline & К-СТь* & $\%$ & К-СТь* & $\%$ & к-Сть* & $\%$ \\
\hline \multicolumn{7}{|c|}{ ЛФ для перорального застосування } \\
\hline Капсули & 46 & 56,2 & 65 & 49,6 & 22 & 46 \\
\hline Таблетки & 28 & 34,1 & 62 & 47,3 & 22 & 46 \\
\hline Настойки & 2 & 2,4 & 1 & 0,8 & 2 & 4 \\
\hline Краплі & - & - & 3 & 2,3 & - & - \\
\hline Чай & - & - & - & - & 2 & 4 \\
\hline Разом & 76 & 92,5 & 131 & 100,0 & 48 & 87,3 \\
\hline \multicolumn{7}{|c|}{ Ректальні ЛФ } \\
\hline Супозиторії & 5 & 6,2 & - & - & 6 & 10,9 \\
\hline Разом & 5 & 6,2 & - & - & 6 & 10,9 \\
\hline \multicolumn{7}{|c|}{ Парентеральні ЛФ } \\
\hline Ліосрілізат для приг. р-ну д/ ін. & 1 & 1,3 & - & - & 1 & 1,8 \\
\hline Разом & 1 & 1,3 & - & - & 1 & 1,8 \\
\hline Всього & 82 & 100,0 & 131 & 100,0 & 82 & 100,0 \\
\hline \multicolumn{7}{|c|}{ *3 врахуванням усіх доз і фрасовок } \\
\hline
\end{tabular}

ISSN 2312-0967. Pharmaceutical review. 2017. № 3 
їнському ринку зареєстрована у вигляді ЛФ для перорального застосування, решта - супозиторії і парентеральні ЛФ. Пероральні ПП сповна представлені твердими ЛФ, позаяк рідких ЛФ для внутрішнього застосування зареєстровано лише 2,4 \%.

На ринку РП присутні тільки пероральні ЛФ. У свою чергу, на ринку РБ понад чотирьох п'ятих ПП представлені ЛФ для перорального застосування, десята частина - супозиторіями, решта - парентеральними ЛФ. Пероральні ПП майже повністю пред- ставлені твердими ЛФ, позаяк рідких ЛФ для внутрішнього застосування зареєстровано лише 1,8 \%.

Висновки. На підставі аналізу даних офріційних реєстрів ЛЗ України, РП і РБ станом на 01.08.2017 р. визначено особливі та схожі характеристики ринків цих держав за асортиментом ПП, структурою їх виробників і заявників, фоорм виходу на ринки, асортиментною залежністю від імпорту та видом ЛФ. Отримані результати є важливими для подальшого фрормування асортиментної політики щодо ПП в Україні.

\title{
АССОРТИМЕНТНАЯ ХАРАКТЕРИСТИКА ПРОСТАТОПРОТЕКТОРОВ, ЗАРЕГИСТРИРОВАННЫХ В УКРАИНЕ, РЕСПУБЛИКЕ ПОЛЬША И РЕСПУБЛИКЕ БЕЛАРУСЬ
}

\author{
И. В. Гадяк'1 Б. П. Громовик² \\ Ивано-Франковский национальный медицинский университет ${ }^{1}$ \\ Львовский национальный медицинский университет имени Данила Галицкого 2 \\ igadyak@ukr.net, hromovyk@gmail.com
}

\begin{abstract}
Цель работы. Изучение особенностей формирования ассортимента лекарственных средств (ЛС) для лечения простатита в Украине, Республике Польша (РП) и Республике Беларусь (РБ).

Материалы и методы. Материалы исследования - данные официальных источников по регистрации ЛС в Украине, РП и РБ состоянием на 01.08.2017 г. Методы исследования - системный, статистический, анализ сравнения, ранжирования, обобщения.

Результаты и обсуждения. Определено, что Украина характеризbhуется более широким (в 1,3 раза) ассортиментом торговых названий (ТН) простатопротекторов (ПП) чем РБ, однако в два раза меньше, чем РП. Лидерами среди зарубежных стран-производителей в Украине является Германия, Индия, Италия, Нидерланды, в РП - Германия, Великобритания, Нидерланды, Франция, в РБ - Украина и Россия. В каждой из исследуемых стран зарегистрированы ПП производства лишь 9 из совокупности 30 государств, а именно Германии, Италии, Нидерландов, Венгрии, РП, Испании, Румынии, Словении и Чехии. Наибольшую часть всего ассортимента ТН ПП в Украине и РП занимают антагонисты альфа-адренорецепторов, в РБ - другие препараты, применяемые при доброкачественной гипертрофии предстательной железы. Показано, что имеет место использование контрактных фрорм выхода на исследуемые рынки. Определено, что на этих рынках существует высокая зависимость ПП от импорта. Установлено, что девять из десяти ТН ПП в Украине зарегистрированы в виде лекарственных фрорм (ЛФ) для перорального применения, остальные - супозитории и парантеральные ЛФ. На рынке РП присутствуют только ЛФ для перорального применения. В РБ свыше четырех пятых ТН ПП представлены пероральными ЛФ, десятая часть - супозиториями, остальные - парантеральными ЛФ.

Выводы. На основании анализа данных офрициальных реестров ЛС Украины, РП и РБ состоянием на 01.08.2017 г. определены особенныеи схожиехарактеристики рынковэтихгосударствпоассортиментуПП, структуреихпроизводителей и заявителей, фрормам выхода на рынки, ассортиментной зависимости от импорта и видам ЛФ. Полученные результаты являются важными для последующего фрормирования ассортиментной политики относительно ПП в Украине.
\end{abstract}

Ключевые слова: простатопротекторы; государственная регистрация (перерегистрация); ассортимент; производители; заявители; срормы выхода на рынок; индекс ассортиментной зависимости от импорта; лекарственная фрорма.

\section{ASSORTMENT CHARACTERISTICS OF PROSTATOPROTECTORS, REGISTERED IN UKRAINE, THE REPUBLIC OF POLAND AND THE REPUBLIC OF BELARUS}

\author{
I. V. Gadyak' ${ }^{1}$ B. P. Hromovyk ${ }^{2}$ \\ Ivano-Frankivsk National Medical University ${ }^{1}$ \\ Danylo Halytsky Lviv National Medical University² \\ igadyak@ukr.net, hromovyk@gmail.com
}

The aim of the work. Studying the peculiarities of the assortment formation of medicines for the prostatitis treatment in Ukraine, Poland and Belarus.

ISSN 2312-0967. Фармацевтичний часопис. 2017. № 3 
Materials and Methods. Materials of research were the data of the official resources of medicine registration in Ukraine, Poland and Belarus dated 01.08.2017. Methods of research - systematic, statistic, comparing analysis, ranking and generalization.

Results and Discussion. It was found out that Ukraine has wider assortment (1.3 times) of the trade names of prostatitis protectors than Belarus, though twice less than Poland. Germany, India, Italy and the Netherlands are the leaders among the foreign state traders in Ukraine. As to Poland, such state leaders are Germany, Great Britain, the Netherlands and France. Only two countries - Ukraine and Russia are the trade leaders in the Republic of Belarus. In each of these countries there are only nine registrated prostatitis protectors manufacturers out of 30, to be more exact in Germany, Italy, the Netherlands, Hungary, Poland, Spain, Romania, Slovenia and the Czech Republic. The most part of all the assortment of registered trade names of prostatitis protectors in Ukraine and Poland belongs to the antagonists alfa-adrenoreceptors, though in Belarus there are medications that are used while benign hypertrophy of prostate gland. The research shows that the usage of contract forms while entering the markets of countries under study is possible. The existence of high dependence of prostatitis protectors on import was also demonstrated. It is states that only nine out of 10 trade names of prostatitis protectors in medical forms for oral application were registered, all the rest are just suppositories and parenteral medical forms. However, in the Polish market only prostatitis protectors in medical forms for oral application are used. Speaking about Belarus more than four fifth of trade names for prostatitis protectors are presented in the medical form of oral application and the tenth part is represented by the suppositories, all the rest - by parenteral medical forms.

Conclusions. Having analyzed the data of the official registration list of medicines in Ukraine, Poland and Belarus dated 01.08.2017 special and similar characteristics of these state markets were defined due to the assortment of prostatitis protectors, structure of their manufacturers and applicants, forms of market entering, assortment dependence upon the import and the kind of medical forms. All the results lay the foundation for further forming of assortment policy as to prostatitis protectors in Ukraine.

Key words: prostatitis protectors; state registration (re-registration); assortment; manufacturers; applicants; forms of entering the market; index of assortment dependence on import; medical form.

\section{Список літератури}

1.Алгоритмасортиментноїхарактеристикитамоніторингу національного і регіональних фрармацевтичних ринків України на прикладі гепатопротекторів: методичні рекомендації /укл. В. П. Попович, Б. П. Громовик. - К. : Управління розвитку фармацевтичного сектора галузі охорони здоров'я МОЗ України, 2011. - 24 с.

2. Аналіз ринку препаратів для лікування доброякісних захворювань передміхурової залози з метою визначення маркетингових можливостей для вітчизняного виробника / В. С. Зайченко, О. М. Євтушенко, О. А. Рубан [та ін.] // ScienceRise: Pharmaceutical Science. - 2017.- № 1. C. 53-61.

3. Державний реєстр лікарських засобів України (станом 01.08.2017) [Електронний ресурс]. - Режим доступу: http://www.drlz.com.ua/.

\section{References}

1. Popovich VP, Hromovyk BP. The assortment characteristics algorithm and monitoring of national and regional Ukraine Pharmaceutical Markets for example of hepatoprotectors. Met. Recom. Management of development pharmaceutical the sector of industry of health protection of Ukraine. 2011:24.

2. Zaychenko VS, Yevtushenko OM, Ruban OA. Analysis of drugs market for the treatment of the disease prostatic hyperplasia in order to identify marketing opportunities for a domestic producer. ScienceRise: Pharmaceutical Science. 2017;1:53-61.

3. State Register of Ukraine Drugs (dated 01.08.2017). Electronic resource: http://www.drlz.com.ua/.
4. Коротков В. А. Сравнительный анализ рынка простатопротекторов Казахстана, Украины, России / В. А. Коротков // Вестник ЮКГФА. - 2013. - № 3 (64). C. 6-10.

5. Маркетингові дослідження препаратів простатопротекторів, представлених на фрармацевтичному ринку України / Д. І. Дмитрієвський, М. М. Кобець, Ю. mМ. Кобець та ін. // Вісник фрармації. - 2012. - № 3 (71). C. 28-31.

6. Реестр лекарственных средств Республики Беларусь (станом на 01.08 2017) [Электронный ресурс]. - Режим доступа: http://www.rceth.by/Refbank/.

7. Baza Leków (Polska, od 01.08.2017) [Resource elektroniczny]. - Dostęp: https://bazalekow.mp.pl/.

4. Korotkov VA. Comparative analysis of prostatis protectors market in Kazakhstan, Ukraine, Russia. Vestnik of the South-Kazakhstan state pharmaceutical academy.2013;3(64): 6-10.

5. Dmitrievsky DI, Kobets MM, Kobets YM. Marketing researches of prostatis protectors presented in the pharmaceutical market of Ukraine. News of pharmacy. 2012;3(71):28-31.

6. State Register of Drugs of Belarus (dated 01.08.2017). Electronic resource. http://www.rceth.by/Refbank/.

7. Baza Leków Polska (od 01.08.2017). Resource elektroniczny. https://bazalekow.mp.pl/. 